\title{
THE INFLUENCE OF ONLINE STORE BELIEFS TOWARDS IMPULSE BUYING (STUDY ON ELEVANIA.CO.ID)
}

\author{
Citra Kusuma Dewi; Despri Lolita br Sinuraya \\ School of Communication and Business \\ Telkom University, Bandung, Indonesia \\ citrakusumadewi@telkomuniversity.ac.id; despri26@gmail.com
}

\begin{abstract}
The rapid development of information technology brings a great impact to all aspects, including the development of business and marketing. The rapid growth of internet user makes online business becomes a potential market. One of the factors that determine the success of an online business is consumer beliefs to an online store. The purpose of this study is to determine the influence of online stores beliefs towards impulse buying on elevenia consumers. This study was conducted on elevenia consumers who have shopped at elevenia.co.id. Sample size of 100 people with purposive sampling method. Data was collected through questionnaires using a 5 point Likert scale to measure 11 indicators. The analysis technique is multiple linear regression. The research found that the online store beliefs variable consist of functional convenience beliefs and representation delight, simultaneously influence impulse buying on elevenia consumers. While in partial functional convenience beliefs variable have no influence towards impulse buying on elevenia consumers.
\end{abstract}

Keywords: online store beliefs, impulse buying, elevenia.co.id

\begin{abstract}
ABSTRAK
Pesatnya perkembangan teknologi informasi membawa dampak yang besar untuk semua aspek, termasuk pengembangan bisnis dan pemasaran. Pesatnya pertumbuhan pengguna internet membuat bisnis online menjadi pasar yang potensial. Salah satu faktor yang menentukan keberhasilan bisnis online adalah keyakinan konsumen terhadap sebuah toko online. Tujuan penelitian untuk melihat pengaruh keyakinan kepada toko online terhadap pembelian tidak terencana pada konsumen Elevenia. Penelitian ini dilakukan pada konsumen Elevenia yang telah berbelanja di elevenia.co.id. Ukuran sampel adalah 100 orang dengan metode purposive sampling. Data dikumpulkan melalui kuesioner dengan menggunakan skala Likert 5-titik untuk mengukur 11 indikator. Teknik analisis yang digunakan adalah regresi linier berganda. Penelitian ini menemukan bahwa variabel kepercayaan kepada toko online yang terdiri dari keyakinan akan kenyamanan fungsional dan representasi yang menyenangkan, secara bersamaan mempengaruhi pembelian tidak terencana pada konsumen Elevenia. Sementara itu, secara parsial keyakinan akan kenyamanan fungsional tidak memiliki pengaruh terhadap pembelian tidak terencana pada konsumen Elevania.
\end{abstract}

Kata kunci: online store beliefs, pembelian tidak terencana, elevaia.co.id 


\section{INTRODUCTION}

Technology has an important role in human life, especially the internet. The increasing of internet users leads the internet is not only used for information and communication facilities, but can also be used as a trade medium known as e-commerce (Nugraha, 2014). The rapid growth in ecommerce indirectly brings new phenomenon or a new lifestyle in Indonesia. E-commerce makes consumers shopped in shorter time without having to linger around the mall to find the desired item. Through the online store, consumers are not impeded by the distance and can be accessed anywhere that makes it easy for consumers to find an online store.

Elevenia.co.id as the first marketplace concept that launched in 2014, is one of online sites in Indonesia that utilizes the development of e-commerce. Elevenia must understand consumer behavior as the target market, to provide assurance to consumers in making a purchase at Elevenia. In order to reap success in Indonesia, the company is necessary to study the unique characteristic owned by Indonesian consumers. According to Irawan, there are 10 characteristics of Indonesian consumer behavior, unplanned characteristics (dominated by unplanned behavior) or I want it now characteristics (Sunyoto, 2013). In online business, the goods traded are intangible, so it is required for an online store to offer, give information, and provide attractive appearance to inflict desire to do impulse buying.

Factors that determine the success of a business, especially an online sale is consumer beliefs to shop online because consumers will experience the process of online shopping decisions such as finding information, comparing alternatives, and decision making. At this stage of information search, consumers will look for reference online. The information sought is in the form of opinions from other people who are already benefiting from the products purchased. So that, as an online store, it is important to observe online store beliefs by making it easier to use, such as a simple search, ease of buying the product, and provide confidence and excitement experience during shopping for consumers (Suhari, 2011).

Online stores beliefs are online transaction which has a certainty and asymmetric information. As a result, there is the need for mutual trust between shoppers and sellers. Online store beliefs same with the perception of functional convenience consisting of merchandise attractiveness and ease of use and representational delight include enjoyment and communication style website (Verhagen \& Van Dolen, 2011). Online store beliefs is one of the factors in the occurrence of unplanned or impulse buying.

According to Engel and Blackwell, unplanned buying is actions of purchases without previous planned or planned in purchase decisions were made at the time were in the stores (in Japarianto \& Sugiharto, 2011). Meanwhile, according to Bloch et al, consumers without intention to buy something from a store, may enter a store and may make impulse buying (Gültekin \& Özer, 2012). According to Stern, there are four types of impulsive purchase (Utami, 2010): (1) Pure impulse; (2) Reminder impulse; (3) Suggestion impulse; (4) Planned impulse.

Based on the explanation and the above factors, a study was conducted to determine the online store beliefs which can lead to impulse purchases on Elevenia.co.id. Based on the background described, the research problem is formulated as follows: (1) How do the online store beliefs on Elevenia consumers?; (2) How does the impulse buying on Elevenia consumers?; (3) How much is the influence of online store beliefs towards impulse buying on Elevenia consumer by partial?; (4) How much is the influence of online store beliefs towards impulse buying on Elevenia consumers insimultaneously? 


\section{METHOD}

The method used is quantitative. Based on the type, this research is a descriptive study to give an idea of the object under study and have a causal relationship. The main data used are primary data, which is acquired by distributing questionnaires to the respondents. The analysis tool used is descriptive analysis and multiple linear regression analysis.

Variables of this research are; (1) Online Store Beliefs (OSB) based on Verhagen \& Van Dolen (2011) theory, which is consisting of two variables; (a) Functional convenience beliefs (FCB) includes ease of use in using the online store which is easy to search and easy to buy products; (b) Representational delight (RD) includes on the characteristics of online shopping with providing trust and online shopping excitement experience for consumers. (2) Impulse buying (IB) is an action of purchases without previous planned or planned in purchase decisions was made at the time were in the stores (Engel in Japarianto \& Sugiharto, 2011).

Population is the generalization region consisting of objects or subjects that have certain qualities and characteristics defined by the researchers to learn and then drawn conclusions (Sugiyono, 2012). The population in this research is the consumer who has purchased a product at Elevenia.co.id in 2014.

The sample is part of the number and characteristics possessed by this population (Sugiyono, 2012). Given the number of the population cannot be known with certainty, then in determining the number of samples using Zikmund approach in order to get the total sample of 97 people, is rounded to 100 people (Zikmund, et al. 2010). The sampling technique in this study is a non-probability sampling technique with purposive sampling, so that each respondent can be filtered through a screening question contained in the questionnaire study.

To analyze the data that has been collected, the researcher used descriptive analysis and multiple linear regression analysis and hypothesis testing using partial test and simultaneous. Multiple linear regression equation as follows:

$$
I B=a+b_{1} F C B+b, R D
$$

IB : Impulse Buying

FCB : Functional Convenience Beliefs

RD : Representational Delight

The framework of this study is described as follows:

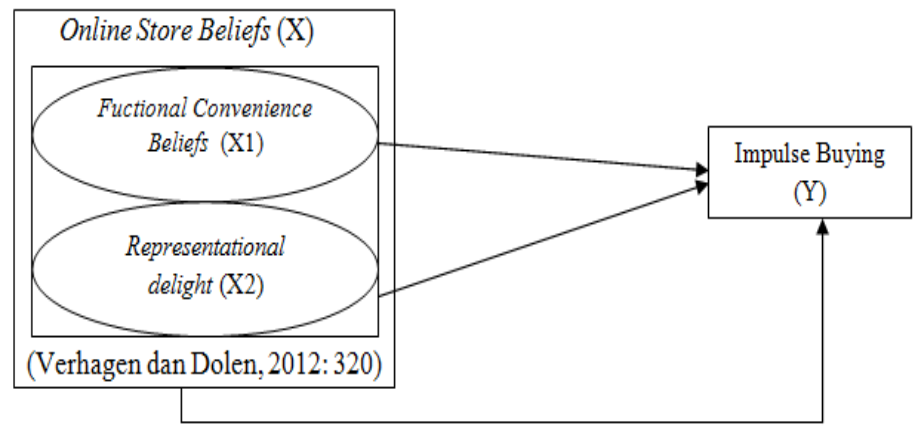

Figure 1 Framework 
Hypotheses from the study; (1) Functional Convenience Beliefs (X1) influence impulse buying (Y) on Elevenia consumers; (2) Representational delight (X2) influence impulse buying (Y) on Elevenia consumers; (3) Online stores beliefs (X) simultaneously influence impulse buying (Y) on Elevenia consumers.

\section{RESULTS AND DISCUSSION}

The results of data processing, descriptive analysis of the results obtained for the three variables shown in Table 1 as follows:

Table 1 Scores and Category

\begin{tabular}{llll}
\hline Variables & $\begin{array}{c}\text { Average } \\
\text { scores }\end{array}$ & $\begin{array}{c}\text { Average } \\
\text { Percentage }\end{array}$ & Category \\
\hline FCB & 1639,5 & $72,93 \%$ & Good \\
RD & 1063,5 & $70,90 \%$ & Good \\
IB & 1432 & $71,6 \%$ & Good \\
\hline
\end{tabular}

From Table 1, it can be explained that FCB consisting of merchandise attractiveness and ease of use is within good category. It can be seen from the average scores obtained in the amount of 72.93\%. It shows that Elevenia as online store provides facilities that are easy to search products and to buy products. DCB is consisting of enjoyment and website communication style is also in a good category, and it can be seen from the average value of scores obtained in the amount of $70.90 \%$. This suggests that Elevania gives confidence to shop online and pleasant shopping experience, such as the colorful appearance of the site and attractive website design. It aims to change the desire of consumers shopping into a pleasure shopping. Impulse buying variable also in a good category, it can be seen from the average scores obtained in the amount of $71.60 \%$. This indicates that the most of Elevenia consumers made the purchases impulse or unplanned as a result of external factors and internal factors. The external factors such as discounts, vouchers, and attractive products, and then the internal factors such as shopping motivation, which came immediately from Elevenia consumers.

\section{Multiple Linear Regression Analysis}

The results showed the regression equation between online stores beliefs towards impulse buying on consumers Elevenia as follows:

$$
\mathrm{Y}=1.263+0,042 \mathrm{X}_{1}+0,512 \mathrm{X}_{2}
$$

The results of this analysis can be shown as follows:

$$
\mathrm{a}=1.263
$$

If functional convenience beliefs variable and representational delight variable are zero then the impulse buying is worth 1,263 units.

$$
\mathrm{b} 1=0,042
$$

If functional convenience beliefs variable (X1) an increase of one unit and the other variable constant, then the variable impulse buying $(\mathrm{Y})$ will increase by 0,042 units. 


$$
\mathrm{b} 2=0,512
$$

If representational delight variable (X2) an increase of one unit and the other variable constant, then the variable impulse buying $(\mathrm{Y})$ will increase by 0.512 units.

Hypothesis Testing

Based on the data processing, it can produce output in Table 2.

Table $2 \mathrm{t}$ test Results (Partial Test)

\begin{tabular}{|c|c|c|c|c|c|c|}
\hline \multirow{2}{*}{\multicolumn{2}{|c|}{$\overline{\text { Model }}$}} & \multicolumn{2}{|c|}{ Unstandardized Coefficients } & \multirow[t]{2}{*}{ Standardized Coefficients } & \multirow[t]{2}{*}{$\mathrm{t}$} & \multirow[t]{2}{*}{ Sig. } \\
\hline & & $\mathrm{B}$ & Std. Error & & & \\
\hline \multirow{3}{*}{1} & (Constant) & 1,263 & ,215 & & 5,881 & 000 \\
\hline & FCB & ,042 & 121 & 050 & ,348 & ,728 \\
\hline & RD & ,512 & ,116 & 635 & 4,420 & ,000 \\
\hline
\end{tabular}

a. Dependent Variable: Impulse Buying

Based on these criterion, it can be explained each of the variables as follows: (1) Functional Convenience Beliefs (FCB), test results for the Functional Convenience Beliefs variable shows that value $(0.348)<\mathrm{t}$ table $(1.985)$ or views of sig $(0.728)>0.05$, then $\mathrm{HO}$ is accepted and Ha rejected, it means that Functional Convenience Beliefs doesn't have influence towards impulse buying on Elevenia consumers. It is possibly because the goods that sold in Elevania are not famous and branded. Goods that sold in Elevenia are from local SMEs that do cooperation with Elevania; (2) Representational Delight Variable, test results for the Representational delight variable shows the value $t=4.420>1.985 \mathrm{t}$ table or views of sig $(0,000)<0.05$, then H0 is rejected and Ha accepted, it means that representational delight has influence towards impulse buying on Elevenia consumers. It shows that Elevenia gives trust to online shopping and gives an enjoyable shopping experience by a display of colored site and website design which draws to change the desire of consumers to get shopping pleasure.

Based on the data processing, it can produce output in Table 3.

Table 3 F Test Results (Simultaneosly Test)

\begin{tabular}{llllll}
\hline Model & Sum of Squares & df & Mean Square & F & Sig. \\
\hline Regression & 18,749 & 2 & 9,374 & 41,447 &, $000^{\mathrm{b}}$ \\
$1_{\text {Residual }}$ & 21,939 & 97 &, 226 & & \\
\hline Total & 40,688 & 99 & & & \\
\hline
\end{tabular}

Based on Table 3, it can be seen the F value (41.447)> F table (3.09) and the Sig. $(0,000)$ $<0.05$. It means that the online store beliefs consisting of Functional Convenience Beliefs and Representational delight have influence towards impulse buying on Elevenia consumers simultaneously. 
Results of this study showed that the representational delight was important to impulsive buying. In order to stimulate impulsive buying, online retailers should create a calm, friendly, knowledgeable, and fun site with an attractive assortment; providing pleasure when customers browse through it (Verhagen \& Dolen, 2011). According to Joseph S., et al(2007), website display would affect impulse buying to consumers. Consumers with high degrees of impulsiveness tend to be more positively influenced by a high-quality website. At the same time, highly impulsive consumers are more negatively influenced by a low-quality website. Thus, while the objective quality of an ecommerce website is an important factor, an understanding of the inherent impulsiveness of the consumer base is a critical factor for understanding how and why consumers react to varying degrees of website quality. Interesting and quality of elevenia website display would make consumers to spend their time to browse the website and it will prevent boredom on consumers. This will make the consumer doing impulse buying.

\section{The coefficient of determination (R2)}

The result of $\mathrm{R}^{2}$ can be seen in table 4 .

Table 4 Coefficient of Determination

\begin{tabular}{lllll}
\hline Model & $\mathrm{R}$ & R Square & $\begin{array}{l}\text { Adjusted } \\
\text { Square }\end{array}$ & RStd. Error of the Estimate \\
\hline 1 &, $679^{\mathrm{a}}$ &, 461 &, 450 &, 47558 \\
\hline
\end{tabular}

Based on the calculations in Table 5, the value of coefficient determination of $46.1 \%$. It can be interpreted that the influence of online store beliefs on Elevenia consumers is $46.1 \%$, as for the rest of $53.9 \%$ influenced by other factors.

\section{CONCLUSION}

Based on the results of the processing of data analysis and discussion that has been described in the previous chapter on the influence of online stores beliefs against impulse buying on Elevenia consumers, researchers can attract some conclusions that can provide answers to the formulation of the problem in this study, as follows: (1) Based on the results of data processing, online stores beliefs has average score of $71.92 \%$, which indicates that the online store beliefs variable is good in the eyes of Elevania consumers. Elevenia is able to provide the convenient transaction and enjoyable shopping experience for every customer; (2) Impulse buying have average total score of $71.60 \%$, which indicates that impulse buying variable is good. It means that most consumers Elevania doing impulse buying when shopping at Elevenia; (3) Based on the results of t test showed that functional convenience variable have not influence towards impulse buying on Elevenia consumers, while the representational delight variable have influence towards impulse buying on Elevenia consumers. In partial Online store beliefs influence impulse buying on Elevenia consumers, those are functional convenience beliefs amount of 3\% and representational delight amounted 43.1\%; (4) Simultaneously influence of online store beliefs against impulse buying on Elevenia consumers. The effect of simultaneously online store beliefs against impulse buying on consumers Elevenia of $46.1 \%$, while the remaining $53.9 \%$ is influenced by other factors, namely: emotional factors, trust factor, demographic factors, the nature of materialism and others. Based on the results of the $\mathrm{F}$ test online store beliefs affect the impulse buying on Elevenia consumers by simultaneously. 


\section{REFERENCES}

Gültekin, Beyza., Leyla Özer. (2012). The Influence of Hedonic Motives and Browsing On Impulse Buying. Journal of Economics and Behavioral Studies, 4(3). 180-189.

Japarianto, Edwin., dan Sugiono Sugiharto. (2011). Pengaruh Shopping Life Style Dan Fashion Involvement Terhadap Impulse Buying Behavior Masyarakat High Income Surabaya. Jurnal Manajemen Pemasaran, 6(1). 32-41.

Nugraha, Firman. (2014). Tekno Jurnal. Data pengguna internet di dunia. Retrieved October $16^{\text {th }}$, 2014 from http://www.worldstats.com/stats.htm

Suhari, Yohanes., et al. (2011). Kepercayaan Terhadap Internet Serta Pengaruhnya Pada Pencarian Informasi Dan Keinginan Membeli Secara Online. Jurnal Dinamika Informatika, 3(1).

Sugiyono. (2012). Metode Penelitian Kuantitatif, Kualitatif, dan R\&D. Bandung: Alfabeta.

Sunyoto, Danang. (2013). Perilaku Konsumen. Yogyakarta: CAPS (Center of Academic Publishing Service).

Utami, Christina. (2010). Manajemen Ritel Strategi Dan Implementasi Operasional Bisnis Ritel Modern Di Indonesia. Jakarta: Salemba Empat.

Valacich, Joseph S., et al. (2007). The Online Consumer's Hierarchy Of Needs. Communications Of The Acm, 5(9). 83-90.

Verhagen, Tiber., dan Willemijn van Dolen. (2011). The Influence Of Online Store Beliefs On Consumer Online Impulse Buying: A Model And Empirical Application. Journal Information \& Management, 48. 320-370.

Zikmund, William, et al. (2010). Business Research Methods, Eight Edition. Canada, South Western Cengage Learning. 